\author{
JACEK MACIEJEWSKI \\ Uniwersytet Kazimierza Wielkiego \\ Bydgoszcz
}

\title{
BISKUP KRAKOWSKI PEŁKA A BITWA NAD MOZGAWĄ W 1195 ROKU*
}

\begin{abstract}
Abstrakt: Artykuł dotyczy końca XII w., kiedy tworzyła się Polska dzielnicowa. W 1195 r., nad rzeczką Mozgawą doszło do jednej z największych bitew w ówczesnej Polsce: wojska krakowsko-ruskie, broniące praw sukcesyjnych synów Kazimierza Sprawiedliwego do tronu krakowskiego, zmierzyły się z siłami wielkopolsko-śląskimi Mieszka III. W wojnie istotną rolę odegrał ordynariusz diecezji krakowskiej Pełka (1186-1207), a analiza relacji o jego udziale w tym starciu, spisanej przez mistrza Wincentego w Chronica Polonorum, jest głównym tematem rozprawy.
\end{abstract}

Słowa kluczowe: historiografia średniowieczna, mistrz Wincenty, bitwa mozgawska, wojowniczy biskupi, ideał biskupa.
Abstract: The article focuses on the end of the twelfth century, the early stage of feudal fragmentation in Poland. In 1195, on the small river of Mozgawa, one of the greatest battles of those times was fought: the Cracow and Ruthenian troops, defending the succession rights of Duke Casimir II the Just's sons to the Cracow throne, pitted themselves against Duke Mieszko III the Old's forces of Greater Poland and Silesia. An important role in the war was played by the ordinary of the Cracow diocese, Bishop Pełka (1186-1207), and an analysis of the account of his participation in the fight, written by Master Vincentius in his Chronica Polonorum, is the main topic of the present study.

Keywords: Medieval historiography, Master Vincentius, battle of Mozgawa, warrior bishops, ideal bishop.

Bitwa mozgawska od zawsze przyciągała uwagę badaczy, co nie może dziwić, gdyż stawką tego starcia było panowanie w Krakowie, a zatem objęcie tronu jeszcze wielkoksiążęcego, za czym szła ciągle dość realna perspektywa władania całą dziedziną piastowską. Już pod koniec XIX w. Stanisław

* Tekst powstał w ramach grantu przyznanego przez Narodowe Centrum Nauki: „Biskupi a wojna w Polsce piastowskiej na tle europejskim”, nr 2014/15/B/HS3/02284. 
Smolka niezwykle celnie zauważył, iż „wraz z trupami poległych w bitwie nad Mozgawą pogrzebano zasadę zwierzchnictwa monarszego krakowskiej stolicy"1. Opinia ta dobrze koresponduje z coraz powszechniej akceptowanym w nowszej historiografii poglądem, że dopiero w okresie po buncie przeciwko władzy Mieszka Starego w 1177 r. rodziła się Polska dzielnicowa, a bój mozgawski może być uważany za zwrotny moment w dziejach średniowiecznego państwa polskiego, oddzielając symbolicznie okres tzw. drugiej monarchii piastowskiej od epoki rozbicia dzielnicowego ${ }^{2}$.

Inaczej niż sama bitwa, udział w niej duchowieństwa nie był dotąd przedmiotem szczególnego zainteresowania badaczy, gdyż zagadnieniem tym zajmowało się bliżej w zasadzie tylko dwóch historyków: Sebastian Bartos oraz Jacek Banaszkiewicz ${ }^{3}$. Pierwszy z nich poruszył kwestię przywództwa biskupa Pełki w obozie broniącym praw sukcesyjnych potomków Kazimierza Sprawiedliwego, pomijając jednak problematykę związaną z samym starciem ${ }^{4}$. Obserwacje drugiego z wymienionych uczonych skupiły się natomiast na osobie kleryka, który w kronice mistrza Wincentego został posłany przez biskupa na zwiady, i w gruncie rzeczy nie dotyczyły jego duchownego statusu. Badacz ten starał się natomiast wniknąć głębiej w strategię pisarską autora relacji o bitwie.

${ }^{1}$ S. Smolka, Mieszko Stary i jego wiek, Warszawa 1881, s. 374. Z innych prac poruszających problematykę związaną z tym starciem zbrojnym wymienić należy przede wszystkim: H. Łowmiański, Początki Polski, t. 6/1, Warszawa 1985, s. 163 n.; J. Rajman, Mieszko Plątonogi, pierwszy książę raciborsko-opolski (1173-1211), KH 19, 1996, 1, s. 33 n.; M. Przybył, Mieszko III Stary, Poznań 2002, s. 115-117; M. Smoliński, Sojusze Mieszka III Starego przed bitwa mozgawska, „Przegląd Zachodniopomorski” 21, 2006, 4, s. 83-105; N. Mika, Mieszko. Książę raciborski i pan Krakowa. Dzielnicowy władca Polski (ok. 1142-1211), Kraków 2010, s. 136 n.

${ }^{2}$ J. Bieniak, Polska elita polityczna XII wieku, cz. 1: Tło działalności, w: Społeczeństwo Polski średniowiecznej, t. 2, red. S.K. Kuczyński, Warszawa 1982, s. 59-61; idem, Polska elita polityczna XII wieku, cz. IIID: Arbitrzy ksiażąt - zmierzch, w: Społeczeństwo Polski średniowiecznej, t. 9, red. S.K. Kuczyński, Warszawa 2001, s. 9-53. Zob. też S. Szczur, Biskupi krakowscy w Polsce piastowskiej. Między tronem a ołtarzem, w: Katedra krakowska w średniowieczu. Materiały sesji oddziału krakowskiego Stowarzyszenia Historyków Sztuki, red. J. Daranowska-Łukaszewska, K. Kuczman, Kraków 1996, s. 16.

3 S.P. Bartos, Post-Gregorian Episcopal Authority and the Struggle for Ducal Krakow, 1177-1210, „The Polish Review” 58, 2013, 3, s. szczeg. 19-23; J. Banaszkiewicz, Narrator w przebraniu, czyli Mistrz Wincenty o bitwie mozgawskiej, w: „Onus Athlanteum”. Studia nad kronika biskupa Wincentego, red. A. Dąbrówka, W. Wojtowicz, Warszawa 2009, s. 423-434 oraz Dyskusja, ibidem, s. 435-442.

${ }^{4}$ Dodać jednak należy, iż w swojej rozprawie doktorskiej badacz ten wyraził też bliski mi pogląd, ale bez bliższego uzasadnienia, że biskup Pełka był dowódcą wojsk krakowskich w czasie inwazji Mieszka III na Kraków, S. Bartos, „Negotiations of Power in a Medieval Society. Ecclesiastical Authority and Secular Rulership in Little Poland, 1177-1320", praca doktorska obroniona na University of New York, 2008, s. 50. 
Sytuacja ta nie dziwi, gdyż problem stosunku polskiego duchowieństwa do kwestii noszenia broni i związków z rzemiosłem wojennym dopiero w ostatnim czasie stał się przedmiotem pogłębionej analizy. Najlepiej przy tym rozpoznana jest ta problematyka odnośnie do działalności dwóch dwunastowiecznych biskupów płockich, Szymona i Aleksandra z Malonne $e^{5}$. Wojenna aktywność pierwszego z nich opisana została już w dziejach dynastii piastowskiej pióra Anonima tzw. Galla ${ }^{6}$. Natomiast obydwaj zostali sportretowani w tym kontekście przez piszącego niemal wiek później mistrza Wincentego ${ }^{7}$. To właśnie w tym ostatnim utworze odnajdujemy również opis zaangażowania się w sprawy militarne kolejnego biskupa polskiego, mianowicie ordynariusza krakowskiego Pełki, i ma to miejsce przede wszystkim przy okazji relacji kronikarskiej o bitwie nad Mozgawą.

Niniejsze wywody można zatem traktować jako uzupełnienie dotychczasowych badań. Natomiast celem podejmowanej analizy jest w pierwszej kolejności wskazanie powodów, dla których mistrz Wincenty przedstawił „wojenną” działalność hierarchy krakowskiego w tak mało czytelny sposób, rozwijając, ale i modyfikując znacząco wypracowane wcześniej schematy narracji, które pozwoliły mu na prezentację działalności ordynariuszy płockich Szymona i Aleksandra. Przekaz o Pełce pozwala nam również jeszcze lepiej zorientować się w poglądach kronikarza, potomka możnego rodu i członka elity kościelnej Małopolski, na kwestie związane z relacjami duchownych, w tym biskupów, z rzemiosłem wojennym. A ponieważ Kadłubkowa relacja to najważniejsze, a przy tym najobszerniejsze źródło do badania przebiegu wypadków w czasie wojny roku 1195, to jej analiza może także przyczynić się do ustalenia, jaką rolę biskup Pełka rzeczywiście odegrał w kampanii wojennej zakończonej bitwą nad Mozgawą.

${ }^{5}$ M. Tomaszek, Modlitwa i łzy bronia biskupa. Pasterze polskiego Kościoła a walka orężna w ujęciu Wincentego Kadłubka, RH 71, 2005, s. 121-136; R. Kotecki, With the Sword of Prayer, or How the Medieval Bishop Should Fight, "Questiones Medii Aevii Novae” 21, 2016, s. $343-$ 371; idem, Ordynariusz płocki Szymon w Gallowej narracji o bitwie Mazowszan z Pomorzanami, w: Ecclesia et bellum. Kościót wobec wojny i zaangażowania militarnego duchowieństwa w wiekach średnich, red. R. Kotecki, J. Maciejewski, Bydgoszcz 2016, s. 142-167; idem, Lions and Lambs, Wolves and Pastors of the Flock. Portraying Military Activities of Bishops in Twelfth Century Poland. A Comparative View, w: Between Sword and Prayer. Warfare and Medieval Clerical World in Cultural Perspective, red. R. Kotecki, J. Maciejewski, J.S. Ott, Leiden-Boston 2018, s. 303-340.

${ }^{6}$ Galli Anonymi Cronicae et gesta ducum sive principium Polonorum, wyd. K. Maleczyński, MPH s.n., t. 2, Kraków 1952, s. 119.

${ }^{7}$ Magistri Vincentii dicti Kadłubek Chronica Polonorum, wyd. M. Plezia, MPH s.n., t. 11, Kraków 1994, s. 92-94. 
W opowieści mistrza Wincentego o starciu nad Mozgawą widzimy na polu bitwy tylko jednego, wspomnianego już, kleryka, zwiadowcę biskupa Pełki. Jednak patrząc na sprawę z szerszej perspektywy, trzeba tu wspomnieć jeszcze o trzech i to nie byle jakich personach. Pierwsza to oczywiście wspomniany już ordynariusz krakowski. Druga, to także biskup, ale in spe, zapewne walczący z mieczem w dłoni bratanek Mieszka Plątonogiego, Jarosław. Książę ten, przejściowo pan Opola, zaledwie trzy lata później został pomazany olejami świętymi, by przez kolejne trzy lata, do swej śmierci, sprawować urząd zwierzchnika diecezji wrocławskiej ${ }^{8}$. Ostatnią wreszcie osobą duchowną, „uczestnikiem” bitwy, jest sam mistrz Wincenty. Nie chodzi tu o domysły niektórych badaczy, zakładających, że kronikarz był osobiście nad Mozgawą, a nawet dopatrujących się jego osoby w wysłanym przez biskupa gońcu, co zresztą uważam za bardzo mało prawdopodobne ze względu na status społeczny ówczesnego prepozyta sandomierskiego. Ważniejsza przecież jest inna okoliczność, a mianowicie ta, że jego dzieło kształtowało przez kilkaset lat dominujące poglądy na przebieg bitwy i opinię o jej wyniku. Cóż z tego, że było to tylko zwycięstwo na pergaminie, a orężem w dłoni przyszłego biskupa było pióro! W pełni zgadzam się z Banaszkiewiczem, że kronikarz z wielkim zaangażowaniem starał się tak prowadzić swój wywód, aby odwrócić uwagę od rzeczywistego przebiegu i wyniku bitwy, uwypuklając w zamian kilka luźno ze sobą związanych epizodów9 Był przy tym, w tym co robił, niezwykle skuteczny.

W relacji kronikarza o bratobójczym starciu w pobliżu opactwa jędrzejowskiego można dostrzec zatem niewielu duchownych, ale za to jeden z nich, krakowski ordynariusz Pełka, jest postacią kluczową dla tego opowiadania. Stała się ona niejako zwornikiem całej narracji o obronie tronu krakowskiego dla potomków Kazimierza Sprawiedliwego przed zakusami innych książąt piastowskich. Hierarcha krakowski pojawia się tutaj w kolejnych obrazach, które autor malował w łączności z pokrętnym opisem samej bitwy.

${ }^{8}$ K. Maleczyński, Jarosław, książę opolski, biskup wrocławski, PSB, t. 11, Wrocław 1964-1965, s. 1; K. Jasiński, Rodowód Piastów ślaskich, t. 1: Piastowie wrocławscy i legnicko-brzescy, Wrocław 1973, s. 63 n.; J. Rajman, op. cit., szczeg. s. 29-32, 34 n. Interesujący bez wątpienia problem przeistaczania się możnych wojowników (w tym książąt) w biskupów, a nierzadko także łączenia władzy świeckiej i duchownej w jednym ręku, pozostawiam do rozpatrzenia na szerszym tle przy innej okazji. W każdym razie przemilczenie przez kronikarza biskupiego statusu Jarosława, który musiał mu być znany w momencie ostatecznej redakcji znanego nam tekstu, uważam za znamienny przejaw solidarności grupowej wyższego duchowieństwa. Czyżby temat ten był zbyt drażliwy?

${ }^{9} \mathrm{~J}$. Banaszkiewicz, Narrator w przebraniu, s. 425-432. 
Sekwencję tę zaczyna publiczne wystąpienie Pełki na wiecu krakowskim po śmierci księcia Kazimierza ${ }^{10}$. Biskup pojawia się w tym miejscu już po raz trzeci w dziele Wincentego i po raz kolejny jest mocno zaangażowany w sprawy doczesne. Zresztą, zauważmy od razu, na kartach kroniki występuje on wyłącznie jako bohater wydarzeń związanych $\mathrm{z}$ wojną i polityką ${ }^{11}$. To on był zatem inicjatorem zwołania narady możnych, a następnie rycerstwa na wiec, na którym roztrząsano kwestię następstwa po Kazimierzu Sprawiedliwym. Co więcej, to biskup osobiście wziął na siebie ciężar obrony porządku ustanowionego po zamachu stanu, przekonując zebranych, że tron krakowski należy zachować dla małoletnich synów tego księcia. Czy była to, jak chce Bartos, próba „implementacji gregoriańskich, hierarchicznych struktur władzy publicznej"? Wątpię. Można się oczywiście zgodzić, że motywy działania hierarchy wawelskiego były związane m.in. z chęcią zapewnienia długofalowych interesów Kościoła poprzez popieranie ładu sukcesyjnego opartego o rozwiązania potwierdzone w $1180 \mathrm{r}$. w Łęczycy ${ }^{12}$. Ale wydaje się, że nie tylko o te interesy chodziło. Mistrz Wincenty pokazuje biskupa krakowskiego działającego na rzecz uporządkowania sytuacji wewnętrznej księstwa krakowskiego, która powstała po śmierci księcia Kazimierza, a celem tych starań miało być przywrócenie ładu społecznego. Za tym zaś kryją się także działania podejmowane w interesie własnej grupy społecznej i kręgu krewniaczego, a także zmierzające do zachowania jeśli nie naczelnej, to przynajmniej samodzielnej pozycji Krakowa w domenie piastowskiej, nawet jeżeli miałoby to oznaczać rezygnację ze zwierzchnich aspiracji, które związane były $\mathrm{z}$ tronem wielkoksiążęcym ${ }^{13}$. Nie od rzeczy będzie także przypomnieć, że Pełka od początku swoich rządów dbał o silną pozycję biskupa krakowskiego w gronie episkopatu polskiego, o czym świadczy papieska bulla protekcyjna, która stała się podstawą do walki o zajęcie przez hierarchów krakowskich pierwszego miejsca wśród

10 Magistri Vincentii dicti Kadłubek Chronica Polonorum, s. 175-178. Wszystkie cytaty w polskim tłumaczeniu pochodzą z: Mistrz Wincenty (tzw. Kadłubek), Kronika polska, tłum. B. Kürbis, Wrocław 1992.

${ }^{11}$ Magistri Vincentii dicti Kadłubek Chronica Polonorum, s. 161, 164: walki o gród krakowski w czasie buntu w roku 1191; lib. 4, c. 18, s. 165 n.: zawarcie układu z królem węgierskim; lib. 4, c. 21, s. 175-178: zwołanie wiecu i aktywna na nim działalność; lib. 4, c. 23, s. 181 n.: wyprawa nad Mozgawę; ibidem, s. 183: objęcie rządów regencyjnych wraz z wojewodą Mikołajem.

12 S.P. Bartos, Post-Gregorian, s. 19 i 21.

13 Por. uwagi J. Bieniaka, Polska elita polityczna, cz. 1, s. 26-29 o przyczynach buntu przeciwko Mieszkowi III w roku 1177. Także idem, Polska elita polityczna, cz. IIID, s. 9-23. 
sufraganów gnieźnieńskich oraz zabezpieczała interesy Krakowa przed nieuzasadnioną ingerencją Gniezna ${ }^{14}$.

Podjęte na wiecu krakowskim decyzje oznaczały wojnę. Nie ograniczyła się ona bynajmniej do obrony Krakowa, ale była prowadzona aktywnie, według przemyślanego planu, który polegał na koncentracji sił krakowskich, sandomierskich i ruskich w jednym miejscu w celu rozbicia armii nadciągającego seniora rodu piastowskiego. Strategia pisarska mistrza Wincentego polega w tym przypadku na podkreśleniu obronnego charakteru działań w interesie osieroconych książąt, którym na pomoc przychodzi książę Roman. Toteż kronikarz natychmiast po przedstawieniu trudnego położenia „sierot” i motywacji księcia Romana przechodzi do opisu samego starcia, celowo, jak sądzę, nie mówiąc wprost o roli biskupa Pełki w tej wyprawie zbrojnej. Trudno w tym wypadku tłumaczyć to tylko skupieniem uwagi autora na czynach książąt i dziejach państwa. W tym bowiem przypadku kronikarz o biskupie napisał całkiem sporo, tyle tylko, że w sposób niejednoznaczny, mając wyraźnie problem z pisaniem w sposób otwarty o udziale Pełki w wojnie przeciwko Mieszkowi III. Czyżby bał się zaszkodzić w jakiś sposób swojemu zwierzchnikowi? I czy ta obawa wypływała z nieprzestrzegania przez niego zaleceń prawa kanonicznego, czy może raczej z aktualnej sytuacji kościelno-politycznej? A może powody takiej strategii literackiej leżą jeszcze w innym miejscu? Zanim podejmę próbę odpowiedzi na te i podobne pytania, wypada prześledzić $\mathrm{w}$ skrócie problematykę związaną z wymaganiami stawianymi duchownym przez Kościół w odniesieniu do angażowania się w sprawy rzemiosła wojskowego.

Od starożytności relacje duchownych chrześcijańskich z profesją wojskową były źródłem napięcia, sporów i konfliktów, co jeszcze bardziej potwierdza się w odniesieniu do czasów późniejszych. Jeśli spoglądamy na działalność prawodawczą Kościoła począwszy od synodów wizygockich i frankijskich aż do działań legislacyjnych wieku XII, to dostrzegamy zazwyczaj jasny zakaz noszenia broni i posługiwania się nią przez kler, ale nierzadko znajdujemy też dozwolone wyjątki (szczególnie w podróży) i ograniczenia odnoszące się do potępienia tej praktyki. Nie ma jednak wątpliwości, że cechą wspólną tego prawodawstwa było odmówienie klerowi służby wojskowej i zabronienie mu noszenia stroju wojskowego

${ }^{14}$ Kodeks dyplomatyczny katedry krakowskiej ś. Wacława, cz. 1, wyd. F. Piekosiński, Kraków 1874, nr 3, s. 6-7; J. Maciejewski, Precedencja biskupów polskich w Polsce piastowskiej, „Nasza Przeszłość” 99, 2003, szczeg. s. 5-10; idem, Episkopat polski doby dzielnicowej 11801320, Kraków-Bydgoszcz 2003, s. 108 n. Por. trochę inaczej J. Dobosz, Monarchia i możni wobec Kościoła w Polsce do początku XIII wieku, Poznań 2002, s. 312. 
i broni ${ }^{15}$. Toteż elity intelektualne XII w. wyraźnie odczuwały etyczną przepaść między rozkazywaniem i prowadzeniem armii, a osobistym uczestnictwem w walce ${ }^{16}$. Co prawda Gracjan, dekretyści oraz dwunastowieczni teolodzy wypowiadali się raczej negatywnie o prowadzeniu wojny przez biskupów, ale konkretne kary groziły tylko za osobisty udział $\mathrm{w}$ walce $\mathrm{z}$ bronią $\mathrm{w}$ ręku oraz dowodzenie rozlewem $\mathrm{krwi}^{17}$. Jeśli nawet $\mathrm{w}$ gruncie rzeczy odmawiano duchownym, w tym i biskupom, prawa do samodzielnego wszczynania wojny, to krytyczny wobec ich osobistego militarnego zaangażowania Gracjan uznał, że biskup może inicjować wojnę i aktywnie uczestniczyć w kampaniach swego seniora, byle w sposób dozwolony ${ }^{18}$. Historyczne doświadczenie, w tym czynne angażowanie się w wojny samych papieży oraz świętych hierarchów Kościoła, a także rozwój ideologii krucjatowej sprzyjały bardziej liberalnemu myśleniu. Wyraziło się ono m.in. w poglądzie Innocentego IV, że biskup, który ma także jurysdykcję świecką, ma prawo prowadzić wojnę i zachęcać swoje oddziały do walki z wrogiem. Zresztą od czasu starcia papiestwa $\mathrm{z}$ cesarstwem $\mathrm{w}$ drugiej połowie XI w. wojna stała się również dozwoloną metodą realizacji polityki kościelnej ${ }^{19}$. Jeszcze swobodniej kwestię tę traktowała ówczesna historiografia. William z Malmesbury posunął się nawet do tego, że włożył w usta Grzegorza VI (1045-1046) długą mowę na temat legalności działań militarnych duchowieństwa. Znalazło się tam twierdzenie bliskie, jak sądzę, sposobowi myślenia kronikarza krakowskiego, iż biskupi mogą prowadzić wojnę, jeśli władza świecka zawiodła, a oni stają się wojownikami w obliczu konieczności ${ }^{20}$.

15 Szerzej L. Duggan, Armsbearing and the Clergy in the History and Canon Law of Western Christianity, Woodbridge 2013, s. 18-23, 90-144.

${ }_{16}$ T. Reuter, „Episcopi cum sua militia”. The Prelate as Warrior in the Early Staufer Era, w: Warriors and Churchmen in the High Middle Ages, red. idem, London-Rio Grande 1992, s. 80 n.

17 F.H. Russell, The Just War in the Middle Ages, Cambridge 1975, s. 72-85, 105-126, 251-255.

18 Ibidem, s. 81.

19 B. Arnold, Medieval German Bishops and their Military Retinues in the Medieval Empire, „German History” 7, 1989, 2, s. 162 n.; Ch.J. Reid Jr., The Rights of Self-Defence and Justified Warfare in the Writings of the Twelfth and Thirteenth-Century Canonists, w: Law as Profession and Practice in Medieval Europe. Essays in Honor of James A. Brundage, red. K. Pennington, Farnham-Burlington 2011, s. 82, 86 n.

${ }^{20}$ D. Gerrard, Fighting Clergy, Church Councils and the Contexts of Law. The Cutting Edge of Orthodoxy or the Ambiguous Limits of Legitimacy, w: Heresy and the Making of European Culture. Medieval and Modern Perspectives, red. A.P. Roach, J.R. Simpson, Farnham-Burlington 2013, s. 280; J.R. Webb, Representations of the Warrior-Bishop in Eleventh-Century Lotharingia, „Early Medieval Europe” 24, 2016, 1, s. 108. 
Trzeba wszakże pamiętać, że dość jednoznaczna pochwała zaangażowania militarnego kleru, którą można spotkać u wielu, mniej lub bardziej współczesnych Wincentemu, autorów z kręgów geograficzne bliskich Polsce (m.in. Saxo Gramatyk, Adam z Bremy, Henryk Łotysz), a nawet w samej Kronice polskiej!, była odnoszona do walk z poganami ${ }^{21}$. Jeśli chodzi o wojny prowadzone między chrześcijanami, to sprawa była bardziej skomplikowana. Prałaci dzierżący regalia byli z reguły, pod groźbą oskarżenia o zdradę, zobowiązani co najmniej do wysyłania kontyngentu zbrojnych (servitium regis), jeśli nie do osobistego wzięcia udziału w wyprawie wojennej ${ }^{22}$. Pojawiały się jednak opinie, że zaangażowani zbytnio w sprawy doczesne hierarchowie nie mogą w ogóle liczyć na zbawienie ${ }^{23}$. A wątpliwości, czy duchowny może uczestniczyć w wojnie przeciwko chrześcijanom, były na tyle silne, że na przykład król Kastylii Alfons X Mądry (1221-1284) zwalniał w takim przypadku kler z obowiązku towarzyszenia armii, co cieszyło się sporą akceptacją społeczną ${ }^{24}$. Przyjrzyjmy się teraz dokładniej działalności biskupa Pełki w czasie bitwy i zaraz po jej zakończeniu. W czasie gdy bój trwał w najlepsze,

${ }^{21}$ C.S. Jensen, Bishops and Abbots at War. Some Aspects of Clerical Involvement in Warfare in Twelfth and Early Thirteenth Century Livonia and Estonia, w: Between Sword and Prayer, s. 411-412. Szerzej o stosunku dwóch najdawniejszych kronikarzy polskich do problemu militarnej aktywności biskupów płockich broniących Mazowsza przed najazdami pogan zob. tamże artykuł R. Koteckiego, Lions and Lambs.

${ }^{22}$ Por. J.L. Nelson, The Church's Military Service in the Ninth Century. A Contemporary View?, w: Politics and Ritual in Early Medieval Europe, red. eadem, London 1986, s. 117-132; F.E. Prinz, Klerus und Krieg im früheren Mittelalter. Untersuchungen zur Rolle der Kirche beim Aufbau der Königsherrschaft, Stuttgart 1971, s. 115-146; J. Keupp, Die Zwei Schwerter des Bischofs. Von Kriegsherren und Seelenhirten im Reichsepiskopat der Stauferzeit, „Zeitschrift für Kirchengeschichte” 117, 2006, s. 1-24; M.R. Pauk, E. Wółkiewicz, „Ministri enim altaris ministri curiae facti sunt”. Ottońsko-salicki „system” Kościoła Rzeszy i jego oddziaływanie w Europie Środkowo-Wschodniej w XI-XII wieku, w: Kościół w monarchiach Przemyślidów i Piastów, red. J. Dobosz, Poznań 2009, s. 110-119. Już Tadeusz Wasilewski, O służbie wojskowej ludności wiejskiej i składzie społecznym wojsk konnych i pieszych we wczesnym średniowieczu polskim, PH 51, 1960, 1, s. 5-6, 8-9, 12, wskazywał na dokumenty mówiące o zwalnianiu przez książąt polskich ludzi biskupich od wypraw wojennych (expeditio), ale przy zachowaniu przez nich obowiązku defensio terrae suae. O podobnych obowiązkach Kościoła w Danii zob. ostatnio N. Lund, The Military Obligations of the Danish Church in the High Middle Ages, w: The Medieval Way of War. Studies in Medieval Military History in Honor of Bernard S. Bachrach, red. G.I. Halfond, Farnham-Burlington 2015, s. 295-308.

${ }^{23}$ T. Reuter, op. cit., s. 79; J. Keupp, op. cit., passim; V. Smirnova, No Way to Salvation for German Bishops? The Case of St. Engelbert of Cologne, w: Saintly Bishops and Bishops' Saints, red. J.S. Ott, T. Verdiš, Zagreb 2012, szczeg. s. 183-187, 192-195.

${ }^{24}$ A. Arranz Guzmán, Cuando el clérigo va a la Guerra. Algunos ejemplos de obispos ,peleadores", w: Guerra y paz en la Edad Media, red. eadem, M. del Pilar Rábade Obradó, Ó. Villarroel Gonzáles, Madrid 2013, s. 277-278. 
hierarcha miał według kronikarza przebywać w miejscu ustronnym lub oddalonym (,in loco semoto”). Niektórzy dawniejsi badacze uznali, że ordynariusz krakowski znalazł wówczas azyl w opactwie jędrzejowskim ${ }^{25}$. Pogląd ten pozostawał zapewne w związku z podjętą przez samego mistrza Wincentego próbą bliższego określenia miejsca bitwy, które miało się znajdować niedaleko wspomnianego klasztoru ${ }^{26}$. Jest to wszakże określenie bardzo ogólne, mające na celu patrzącemu z pewnego oddalenia czytelnikowi przybliżenie rejonu, w którym doszło do rzeczonego starcia poprzez odwołanie się do lokalizacji powszechnie znanej i łatwo rozpoznawalnej. Nie wynika jednak z tego w żadnym razie, że bitwa rozegrała się w najbliższej okolicy Jędrzejowa. Jan Długosz sądził, że Mieszko Stary rozbił swój obóz nad rzeczką Mozgawą cztery mile od klasztoru jędrzejowskiego. Ordynariusz krakowski miał zaś stanąć wówczas w dobrach biskupich we wsi Dzierążna, oddalonej od pola bitwy o dwie mile ${ }^{27}$. Należy przypuszczać, że kanonik krakowski, podejmując próbę bliższego określenia miejsca pobytu hierarchy, wziął pod uwagę trzy elementy: położenie znanej mu wsi Mozgawa, położenie opactwa w Jędrzejowie oraz domniemany kierunek uciekinierów krakowskich z pola bitwy. W konsekwencji uznał, zresztą słusznie, że naturalny kierunek ucieczki nie powinien znajdować się na północ od miejsca starcia i nie próbował umieszczać biskupa w klasztorze. Takie rozwiązanie jest także nie do przyjęcia z innych względów. Przebywający w Jędrzejowie Pełka byłby w oczywisty sposób zagrożony dostaniem się do niewoli Mieszka, a poza tym wojska wielkopolsko-śląskie mogłyby łatwo odciąć mu najbliższą drogę na Wawel.

Podane przez kanonika krakowskiego odległości świadczą wyraźnie, że był on przekonany, iż bitwę stoczono w okolicach dzisiejszej wsi Mozgawa, oddalonej od Jędrzejowa o ok. $33 \mathrm{~km}^{28}$. Trudno w tej chwili rozstrzygnąć, gdzie dokładnie, ale w pewnym oddaleniu w okolicy znajdują się dwie rzeczki, które wyznaczają obszar poszukiwań: Mozgawa (Wodzisława), prawobrzeżny dopływ Mierzawy, prawego dopływu Nidy, oraz Mozgawka, prawy dopływ Nidy ${ }^{29}$. Zaproponowane zatem przez Długosza

25 S. Smolka, op. cit., s. 372; B. Włodarski, Polska i Ruś 1194-1340, Warszawa 1966, s. 19.

${ }^{26}$ „Est autem in Cracouiensi prouincia locus a nomine fluuii Moscaua dictus, ab Andreouiensi cenobio non longe dystans", Magistri Vincentii dicti Kadłubek Chronica Polonorum, s. 179.

${ }^{27}$ Joannis Dlugosii Annales seu cronicae Incliti Regni Poloniae, lib. 5-6, t. 3, wyd. Z. Kozłowska-Budkowa et al., Warszawa 1973, lib. 6, s. 162, 164.

${ }^{28}$ Dla porównania, w tej samej szóstej księdze Annales, s. 189, znajduje się informacja, że Trzebnica jest oddalona od Wrocławia o trzy mile.

${ }^{29}$ Rocznik świętokrzyski, wyd. A. Rutkowska-Płachcińska, MPH s.n., t. 12, Kraków 1996, s. 30, przyp. 109. 
miejsce pobytu Pełki we wsi Dzierążna w momencie trwania bitwy jest bardziej prawdopodobne, choć nie sądzę, by było czymś więcej niż kronikarskim domysłem. Ta wieś parafialna graniczyła bowiem z sąsiednią parafią w Działoszycach i można założyć, że dzieliło ją od obszaru, na którym stoczono bój, co najmniej kilkanaście kilometrów ${ }^{30}$. Wincenty nazywa samo miejsce ustronny m czy też oddalonym w odniesieniu do pola bitwy. Niewiele z tego wynika poza podkreśleniem, że Pełka nie brał osobiście udziału w starciu zbrojnym, nawet w sposób dla duchownego dozwolony. Późniejszy rozwój wydarzeń wskazuje jednak na to, iż było to jakieś pobliskie miejsce, być może obóz wojsk wiernych Kazimierzowicom, skoro co i rusz przybywali właśnie tutaj uciekinierzy z bitewnego pola, reprezentujący krakowską stronę zmagańn ${ }^{31}$.

Według relacji kronikarza biskup oczekiwał tam z obawą i nadzieją na wynik starcia, a oczekiwanie to wypełniała mu żarliwa modlitwa. Czyżby zatem po raz kolejny w swym dziele kronikarz odwoływał się do wyraźnie wyartykułowanej przez Gracjana tzw. zasady ambrozjańskiej, iż „bronią biskupa są łzy i modlitwa”, a hierarchowie powinni zachowywać się na wzór Mojżesza czy Aarona, wypraszając pomoc Bożą dla swych oddziałów ${ }^{32}$ Mieli tak postępować nie tylko opisywani przez Wincentego biskupi płoccy XII w., Szymon i Aleksander, ale w podobny sposób został ukazany już wcześniej także biskup Pełka. Chodzi tu o dychotomiczne przedstawienie działań ordynariusza Krakowa w czasie buntu przeciwko Kazimierzowi Sprawiedliwemu w roku 1191. Najpierw Pełka osobiście organizuje obronę stolicy księstwa, lecz jego zaangażowanie nie na wiele się zdaje, gdyż buntownicy opanowują Wawel. Gdy jednak sytuacja się odwróciła i wojska Kazimierza przygotowywały się do szturmu na gród broniony przez zwolenników Mieszka III, to ordynariusz krakowski miał odegrać niezwykle istotną rolę. On to bowiem, porównywany w tym miejscu do proroka Elizeusza broniącego Dotan, miał swoją okraszoną łzami modlitwą otumanić obrońców Krakowa, którzy sądząc, że gród się pali, dobrowolnie oddali się w niewolę przybywającemu księciu Kazimierzowi ${ }^{33}$.

30 Por. J. Długosz, Liber beneficiorum dioecesis Cracoviensis, t. 3, w: Joannis Dlugossi Opera omnia, t. 9, wyd. A. Przezdziecki, Kraków 1864, s. 105, 362, 366; S. Litak, Struktura terytorialna Kościoła łacińskiego w Polsce w roku 1772, Lublin 1979, s. 211.

${ }^{31}$ Pełka pyta przecież pierwszego z nich: „prospere nobiscum agitur?”, Magistri Vincentii dicti Kadłubek Chronica Polonorum, s. 181.

${ }^{32}$ F.H. Russell, op. cit., s. 77-80. Zob. ostatnio znakomitą analizę tego problem w: R. Kotecki, With the Sword of Prayer.

33 „Vestros quoque captiuos non absimilis cecitatis caligine Dominus inuoluit, illacrimante plus quam propheta cum omni ecclesie sue deuotione sacro Cracouiensium 
Odwołanie się zatem przez naszego kronikarza przy okazji bitwy mozgawskiej do motywu modlitwy wypraszającej zwycięstwo oczywiście nie dziwi, skoro - jak wiemy - Kościół pozwalał na niesienie pocieszenia duchowego, zagrzewanie do walki, udzielanie rady i zanoszenie modłów za wojowników. Taka aktywność biskupów niekiedy prowadziła ich jednak nie tylko w pobliże pola walki, ale nierzadko także na to pole wkraczali, by całkiem realnie wpływać na przebieg starcia ${ }^{34}$.

Biskupi na polu bitwy to nawet dość powszechny widok w czasach Wincentego. I nie chodzi tu o skrajne przypadki ewidentnych bellatores, takich choćby jak arcybiskup koloński Rajnald z Dassel czy metropolita moguncki Chrystian ${ }^{35}$, których krwawe wyczyny bulwersowały współczesnych i przywoływały na myśl wzorce literackie z Pieśni o Rolandzie czy Pieśni o Cydzie. Według współczesnego naszej kronice źródła biskup Bayeux, Odo, przedstawiony jako „dobry kapłan”, w czasie bitwy pod Hastings, gdy część wojsk księcia Wilhelma była o krok od załamania się i ucieczki, zawołał do swoich, uspakajając ich i napełniając otuchą. Obiecał im, że zwyciężą, po czym spiął konia i pognał tam, gdzie bitwa była najgorętsza. Na białą koszulę miał założoną krótką kolczugę, obszerną z obszernymi rękawami, a siedział na białym koniu i każdy mógł go rozpoznać. $\mathrm{W}$ dłoni zaś trzymał pałkę czy maczugę (,un baston teneit en son poing”) i wydawał rozkazy, nakazując stać lub ruszyć do ataku i uderzyć na wroga ${ }^{36}$.

Wincentemu, choć nigdy nie posunął się tak daleko, by sportretować biskupa w kolczudze lub z bronią w ręku, nieobce było aktywne zaangażowanie się polskich biskupów w sprawy militarne. Najlepszym

antistite", Magisteri Vincentii dicti Kadłubek Chronica Polonorum, p. 164; J. Maciejewski, A Bishop Defends His City, or Master Vincentius's Troubles with the Military Activity of His Superior, w: Between Sword and Prayer, s. 345-346.

${ }^{34}$ Błagalna modlitwa o zwycięstwo była przy tym atrybutem monarchów i biskupów, D. Bachrach, Military Chaplains and the Religion of War in Ottonian Germany, 919-1024, „Religion, State and Society” 39, 2011, 1, s. 19 n.

${ }^{35}$ Ten pierwszy, oblężony w 1167 r. w Tusculum, gdy ujrzał nadchodzącą odsiecz, wyskoczył z miasta z małym oddziałem i zmasakrował rozproszonych oblegających. Natomiast drugi budził przerażenie i niemiłosiernie gnębił wraz ze swoimi najemnikami w roku 1172 Lombardię i Toskanię, a w bitwie pod Bolonią walczył konno ubrany w pełną zbroję i pozłacany hełm, a za jednym zamachem mógł ubić dziewięciu wrogów, B. Arnold, op. cit., s. 164; T. Reuter, op. cit., s. 80 n.; J, Keupp, op. cit., s. 2 n.

${ }^{36}$ Maistre Wace's Roman de Rou et des Ducs de Normandie, wyd. H. Andresen, Heilbronn 1879, s. 352 n. Autor ten bardzo mocno podkreśla duchowe wsparcie, jakie mieli nieść biskupi i inni duchowni przed bitwą. Geoffrey biskup Coutances oraz biskup Bayeux Odo słuchali spowiedzi i udzielali błogosławieństwa, kapłani zaś z ich kaplic rozłożonych w różnych miejscach armii czuwali całą noc, wzywając Boga i modląc się do niego. Pościli i czynili pokutę, zanosili prywatne modły, recytowali psalmy, Miserere, litanie i prośby, odmawiali Ojcze nasz, oraz odprawiali msze wotywne, ibidem, s. 321 n. 
przykładem jest tu Aleksander z Malonne, którego obraz został skonstruowany dychotomicznie jako jednocześnie pobożnego biskupa i walecznego rycerza. Także poprzednik Aleksandra na katedrze płockiej, Szymon, powstrzymuje przecież w jego kronice oddział Mazowszan, którzy, przerażeni przewagą Pomorzan, zamierzają wycofać się, a nawet wręcz uciec. Dopiero po tej krótkiej ekshortacji ordynariusz płocki poświęca się modlitwie. Kronikarz kładzie też nacisk na brak związku hierarchy mazowieckiego z polem bitwy. Szymon słowa otuchy wykrzykuje bowiem $\mathrm{z}$ daleka, a następnie, wyprawiwszy oddział do walki, udaje się na modlitwę. Inaczej niż u Galla, hierarcha ten nie jest wprost porównywany z Mojżeszem, więc autor nie sugeruje, że w trakcie modlitwy bitwa znajdowała się w zasięgu jego wzroku ${ }^{37}$. Inna rzecz, że o skuteczności modłów biskupich nie decydowała ani odległość, ani kontakt wzrokowy. W czasie wojny przeciw Szkotom w roku 1138 arcybiskup Thurstan pozostał ze względów zdrowotnych w Yorku i wspomógł swoich modlitwą, odprawianiem wigilii, postami „i wszystkim co do Boga należy”38. U Henry'ego z Huntingdon z kolei znajdujemy obraz biskupa Wulfstana modlącego się gorąco przed ołtarzem w oblężonym Worcester, a w tym samym czasie jego nieliczne wojsko gromiło wielką liczbę nieprzyjaciół ${ }^{39}$. Szczególnie interesującą analogię do sytuacji nad Mozgawą znajdujemy w kronice Henryka Łotysza. W 1206 r. biskup Albert von Buxhövden wysłał przeciwko groźnemu wodzowi Liwów oddział złożony głównie z kawalerów mieczowych. A gdy oni zdobywali gród Holme, hierarcha inflancki wraz ze swoimi księżmi odprawiał mszę. Kronikarz opowiada przy tym, że Albert modlił się pełen bojaźni Bożej, a przy tym z sercem wypełnionym wiarą w Pana, i oczekiwał na przybycie kogoś, kto poinformuje go o wyniku tego starcia ${ }^{40}$.

Modlitwa była zatem powszechnie znanym i stosowanym rytem wojennym, obecność hierarchy kościelnego zaś przy wojsku sytuacją zwyczajną. Patrząc z tego punktu widzenia przedstawienie przez

37 "Quo dicto suos pugne, sese orationi committit nec cessat, donec omnis illa predonum numerositas succubuit, paucis admodum fuga elapsis", Magistri Vincentii dicti Kadłubek Chronica Polonorum, s. 94. Por. Galli Anonymi Cronicae et gesta, s. 119. Zob. też analizę i porównanie obu przekazów u R. Koteckiego, Lions and Lambs, s. 319-321.

38 D.S. Bachrach, Religion and the Conduct of War, c.300-c.1215, Woodbridge 2003, s. 155.

${ }^{39}$ K.A. Fenton, Writing Masculinity and Religious Identity in Henry of Huntingdon, w: Religious Men and Masculine Identity in the Middle Ages, red. P.H. Cullum, K.J. Lewis, Woodbridge 2013, s. $72 \mathrm{n}$.

40 „Erat autem episcopus cum clericis suis celebrata missa in Die timore et orationibus expectans, si forte quispian appareret referens ei quid ageretur. Erat autem cor eius fiduciam habens in Domino", Heinrici Chronicon Livoniae, wyd. 2, wyd. L. Arbusow, A. Bauer, MGH SrG, Hannoverae 1955, s. 38. 
kronikarza modlącego się biskupa Pełki wydaje się zabiegiem naturalnym. Jest jednak jedna rzecz, która może tu dziwić. Otóż autor z jakichś ważnych powodów nie wypowiedział się wprost o intencji tej biskupiej oracji. Czyżby chodziło o jej skuteczność? Oto książę Roman ranny uchodzi ze swoimi oddziałami, krakowianie idą w ich ślady, wojewoda Goworek dostaje się do niewoli, a przeciwnicy podnoszą na polu bitwy swe znaki zwycięstwa. Choć Wincenty robił co mógł, by złagodzić wydźwięk tych faktów, to dla współczesnych było oczywiste, że trudno nazwać ten dzień pomyślnym dla obrońców panowania Kazimierzowiców w Krakowie! Gdyby więc Pełka został tu przedstawiony, niczym płocki Szymon proszący niebiosa o zwycięstwo swoich, to jakże nieskuteczne byłyby to modły. Czyż nie poddano by w wątpliwość kwalifikacji biskupa jako najwyższego kapłana i jego relacji ze Stwórcą? Czy uniknięto by pytań o przyczynę, która nie pozwoliła, aby modlitwa została wysłuchana?

Biskupia modlitwa w średniowiecznych relacjach historiograficznych ma z reguły ogromną moc. Czasami jednak pewne okoliczności mogły spowodować jej całkowitą bezsilność. W hiszpańskiej Kronice cesarza Alfonsa zawarta jest opowieść o bitwie, która rozegrała się pod twierdzą Fraga w roku 1134. Według dziejopisa Bóg, „ze względu na grzechy króla", pozwolił obrońcom doczekać odsieczy, a w jej wyniku obóz chrześcijan został oblężony przez przeważające siły wroga. Gdy obrońcy spostrzegli, w jak trudnej sytuacji się znaleźli „biskupi, kler i cały lud chrześcijański zaczęli prosić Pana Boga, aby wybawił ich z rąk Saracenów i by nie pamiętał grzechów króla, ani jego krewnych, ani tych, którzy z nim byli, lecz by ukarał ich łagodnie, jako zapłatę za ich grzechy. Ich modły nie zostały wysłuchane przez Boga, ponieważ archanioł Gabriel, najważniejszy posłaniec Boży, nie zaniósł ich przed sędziowski tron Chrystusa, ani Michał, wódz niebiańskiej armii, nie został posłany przez Boga, by im pomóc w tej bitwie"41.

A zatem to grzechy króla Aragonii i Nawarry Alfonsa I Walecznego oraz jego otoczenia sprawiły, że modlitwa biskupów nie została wysłuchana. Dla mistrza Wincentego także musiało być jasne, że coś zakłóciło relacje między zwierzchnikiem diecezji krakowskiej i Stwórcą, skoro jego modlitwa okazała się nad Mozgawą tak mało skuteczna. Trudno

41 „episcopi, et clerici, et omnis populus christianourum coeperunt rogare Dominum Deum, ut eos eiperet de manibus Sarracenorum, et ne reminisceretur peccatorum regis, neque parentum suorum, vel qui cum eo erant, ut ab ipso mitius corriperentur. Sed, peccatis exigentibus, orationes eorum non sunt exauditae ante Deum, quia Gabriel Archangelus, summus nuntius Dei, non tulit eas ante tribunal Christi nec Michael princeps militiae caelestis, missus ast a Deo ut eos adiuvaret in bello", Chronica Adefonsi imperatoris, wyd. L. Sánchez Belda, Madrid 1950, s. 45 n. 
było jednak kronikarzowi postawić własnego ordynariusza w niezręcznej sytuacji, oskarżając go o brak kwalifikacji kapłańskich i sprzyjanie grzechowi. Jednocześnie, choć nie wprost, diagnoza została postawiona zaraz na początku opisu samej bitwy. Przecież był to bój bratobójczy, który zachwiał ładem moralnym panującym w Rzeczypospolitej i swojego stosunku do niego kronikarz nie ukrywa: „O sacrilega, o prophana, o luctuosa congressus eiusdem spectacula!" 42 .

W sferze ideologicznej Pełka u Wincentego ma dość ograniczone możliwości. Nie wypada mu modlić się wprost o zwycięstwo w bitwie, w której nawet sam udział jest świętokradztwem. W tej sytuacji biskup nie powinien w niej w ogóle uczestniczyć, nawet stosując dozwolone przez Kościół środki pomocy swoim oddziałom, a raczej działać w miarę swych możliwości na rzecz pokoju. Oczywiście ta negatywna moralna ocena starcia dotyczyła obu stron. Wojna ta była bowiem, by użyć określenia poety rzymskiego Lukana czy też Izydora z Sewilli, a zatem dobrze znanych Wincentemu autorów, czymś więcej niż wojną domową, bowiem tu brat występował przeciw bratu ${ }^{43}$. W miejscu bitwy zapanował więc apokaliptyczny porządek, a toczoną wojnę trudno było nazwać sprawiedliwą, choć Wincenty próbował przedstawiać ją jako obronę ojczyzny ${ }^{44}$. Zauważmy także, iż dla Jana Długosza, który nie musiał niczego kamuflować i udawać, bo nie dotyczyły go już namiętne spory z przeszłości, ordynariusz krakowski rzecz jasna „modlił się o zwycięstwo dla swoich"45.

Kronikarz przedstawia zatem modlitwę biskupa jako oczekiwanie, że Stwórca zdecyduje o wyniku tego świętokradczego starcia. Zdaje się więc z nadzieją, ale i obawą, na wyrok najwyższego sędziego, co oznacza,

${ }^{42}$ Magistri Vincentii dicti Kadłubek Chronica Polonorum, s. 180. O stosunku kronikarza do wojen domowych zob. B. Kürbis, Jak mistrz Wincenty pisał historię Polski, w: Mistrz Wincenty Kadłubek. Człowiek i dzieło, pośmiertny kult i legenda, red. K. Prokop, Kraków 2001, s. 69.

43 Izydor z Sewilli, Etymologiarum libri XX, PL, t. 82, kol. 639. Bezpośrednio z Lukana (Pharsalia) motyw ten zaczerpnął dla przykładu kronikarz czeski Kosmas: L. Wolverton, Cosmas of Prague: Narratives, Classicism, Politics, Washington 2015, s. 206. Tak samo Galli Anonymi Cronicae et gesta, s. 72. O znajomości przez mistrza Wincentego tekstów wskazanych autorów: B. Kürbis, Wstęp, w: Magistri Vincentii dicti Kadłubek Chronica Polonorum, s. XCVIII, CXV; K. Chmielewska, Recepcja rzymskiej literatury antycznej w „Kronice polskiej” Mistrza Wincentego, w: „Onus Athlanteum”, s. 218 n., 223.

${ }^{44} \mathrm{~J}$. Banaszkiewicz, Narrator w przebraniu, s. 425; P. Wiszewski, Polska w kronice Mistrza Wincentego. Ze studiów nad terminologia dzieła i hierarchiami wartości w Polsce pełnego średniowiecza, w: „Onus Athlanteum”, s. 88 n. O pojęciu wojny sprawiedliwej w tym czasie zob. F.H. Russell, op. cit., rozdz. 3-4; Ch.J. Reid Jr., op. cit., s. 81-83.

${ }^{45}$ „suis victoriam cedere precabatur”, Joannis Dlugosii Annales, lib. 6, s. 164. 
że bój ten potraktowany został tutaj jako sąd Boży ${ }^{46}$. Takie podejście do wojny domowej nie było niczym nowym, nawet na gruncie polskim. Ten sposób widzenia sprawy mógł bowiem Wincenty z łatwością przyjąć za kroniką Galla. Ten ostatni autor, opisując krwawą bitwę kruszwicką między oddziałami księcia Władysława Hermana a stronnikami jego syna Zbigniewa, wyraźnie przecież stwierdził, że to „sprawiedliwy Sędzia rozsądził sprawę między ojcem a synem" 47 .

Zbigniew wszakże w relacji kronikarskiej stoi na straconej pozycji, bo występuje przeciw ojcu i to z pomocą pogan. Tymczasem nad Mozgawą sytuacja nie jest tak oczywista. W związku z tym towarzyszący biskupowi Pełce strach nie może dziwić, ani też nie przynosi mu ujmy. Zresztą postawa ta okazała się - przynajmniej w opowiadaniu Wincentego - bardzo skuteczna. Bóg bowiem dokonał cudu i zmienił klęskę w zwycięstwo, każąc okrutnie sprawców napaści, księcia Mieszka i jego syna. Właśnie te dwa fakty, odpowiednio uwypuklone, pozwoliły kronikarzowi na swobodne budowanie narracji w oparciu o założenie, iż Boży trybunał przyznał słuszność Pełce i krakowianom. Trzeba było pójść tą drogą, gdyż nie sposób było wyniku takiego starcia traktować jako niesprawiedliwego. Anonimowy autor Vita Balderici, zapewne z XII w., klęskę armii biskupa Liège Balderica II (1008-1018) pod Hoegaarden w roku 1013 potraktował także jako wynik sądu Bożego. Nie miał przy tym wątpliwości, że wyrok był sprawiedliwy, choć powody takiego rozstrzygnięcia zdawały się być dla wielu nieodgadnione ${ }^{48}$.

Modlitwa w ukryciu to jedyny moment, gdy Pełka zachowuje się w zasadzie biernie wobec zachodzących zdarzeń. Pozostałe działania biskupa przed bitwą i tuż po niej wskazują natomiast na nadzwyczajną wręcz aktywność ordynariusza krakowskiego. Zanim jednak prałat ten mógł wrócić do swej przywódczej roli, Wincenty musiał jakoś ponownie związać jego osobę ze zmaganiami wojennymi. Oto pozostające gdzieś na uboczu miejsce oczekiwania świty biskupa regularnie odwiedzają

46 O pojmowaniu bitwy przez kronikarzy średniowiecznych jako szczególnego rodzaju sądu Bożego (ordalium), który odnoszono szczególnie chętnie do wojen domowych zob. M. Clauss, Der Krieg als Mittel und Thema der Kommunikation. Die Narrative Funktion des Gottesurteils, w: Gottes Werk und Adams Beitrag. Formen der Interaktion zwischen Mensch und Gott im Mittelalter, red. T. Honegger, G. Huber-Rebenich, V. Leppin, Berlin 2014, s. 128-141.

${ }^{47}$ Anonim tzw. Gall, Kronika polska, tłum. R. Grodecki, Wrocław 1989, s. 71; „iustus iudex inter patrem et filium iudicavit", Galli Anonymi Cronicae et gesta, s. 72.

48 „est ad urbem nostram tantae calamitatis cognitio, triumphus hostium, episcopi fuga, sui ruina exercitus, occultum sed nunquam iniustum Dei iudicium", Vita Balderici episcopi Leodiensis, MGH SS, 4, wyd. G.H. Pertz, Hannoverae 1841, s. 728; J.R. Webb, op. cit., s. 121. 
uczestnicy boju, którzy zdają sprzeczne relacje o jego wyniku. Zauważmy, że jak na miejsce podobno oddalone od bitewnego zgiełku, to duży panuje tam ruch. Wobec rozbieżnych informacji przekazywanych Pełce, hierarcha decyduje się na zbadanie sprawy poprzez własnego gońca, który ma ustalić, co tak naprawdę dzieje się na polu bitwy. Według Banaszkiewicza mamy tu do czynienia przede wszystkim z literacką sztuczką pisarza, który robi co może, by w sposób „absolutnie wiarygodny” poinformować czytelnika o wyniku bitwy, przedstawiając go znacznie korzystnej dla strony krakowskiej, niż to było w rzeczywistości ${ }^{49}$. Interpretacja ta wydaje się być przekonująca. Wszak pogląd Izydora z Sewilli domagającego się od historyka, by był naocznym świadkiem opisywanych zdarzeń, zyskał powszechną aprobatę $\mathrm{w}$ wiekach średnich. Powoływanie się na takich świadków stanowiło wręcz o „prawdziwości” danej relacji, a wykazanie, iż opiera się ona o przekaz z pierwszej ręki, w sprawach spornych przeważało nad innymi argumentami ${ }^{50}$. Świetnie $\mathrm{z}$ tymi poglądami koresponduje passus z kroniki mistrza Wincentego, z reguły uważany za świadectwo samego autora: „Widział bowiem Wincenty, który to napisał - a wiemy, że świadectwo jego jest prawdziwe" 51 .

Wysłannik biskupi był, jak się dowiadujemy, kimś z najbliższego otoczenia hierarchy, a kronikarz określa go mianem clericus. Termin ten mógł mieć wówczas wiele znaczeń i można było tak określić zarówno kapłana, kogoś, kto przyjął choćby jedno z niższych święceń, a nawet chłopca, który otrzymał tonsurę jedynie na znak, że jego intencją jest przyjęcie święceń w przyszłości ${ }^{52}$. Niezależnie od tego, o kogo chodziło, to mamy tu do czynienia $\mathrm{z}$ duchownym w szerokim rozumieniu tego słowa.

Wprowadzenie jednego $\mathrm{z}$ grona oratores w apokaliptyczny świat splamiony braterską krwią poprzedza pozbawienie go kleryckiego stroju. Sam akt zrzucenia szat duchownego może zaciekawiać. Wincenty czyni to w określonym celu, nie zważając na pewne problemy, które rodzi taka konstrukcja literacka. Duchowni byli bowiem od co najmniej VI-VII stulecia zobowiązani do noszenia także poza świątynią - i również bez związku z czynnościami liturgicznymi - odzienia

49 J. Banaszkiewicz, Narrator w przebraniu, s. 432.

50 E. Lapina, Warfare and the Miraculous in the Chronicles of the First Crusade, Philadelphia 2015, s. 15-36.

${ }^{51}$ Mistrz Wincenty (tzw. Kadłubek), Kronika polska, s. 229; „Vidit enim Vincentius qui scripsit hec, et scimus quia verum est testimonium eius", Vincentii dicti Kadłubek Chronica Polonorum, s. 165.

${ }^{52}$ R. Kiechhefer, Magic in the Middle Ages, Cambridge 1989 (tu cyt. wyd. 2014), s. 353. O święceniach duchownych zob. R.E. Reynolds, Clerical Orders in the Early Middle Ages. Duties and Ordination, Aldershot-Brookfield-Singapore-Sydney 1999. 
charakterystycznego dla swojego ordo ${ }^{53}$. Ale dla autora relacji o Mozgawie liczy się przede wszystkim przemiana, której celem jest okpienie nieprzyjaciół, bo z chwilą zmiany odzienia kleryk-ochotnik przeistacza się w kogoś innego ${ }^{54}$. Zrzucając strój duchownego, przemienia się w osobę scharakteryzowaną przez autora dwoma terminami: scurra i cursor. Każdy $\mathrm{z}$ nich określa owego przebierańca $\mathrm{z}$ innego punktu widzenia. Pierwsze bowiem pojęcie odnosi się do jego wyglądu ${ }^{55}$, drugie zaś do przydanej mu w danej chwili funkcji biskupiego wysłannika (posłańca/zwiadowcy). Powód tej maskarady został niedawno trafnie rozszyfrowany. Chodzi o to, iż w średniowieczu ludzie z nizin społecznych, czy też osoby znajdujące się na marginesie społecznym i intelektualnym (ubodzy, upośledzeni, żebracy), byli traktowani w sposób przedmiotowy, a ich obecność ledwie była zauważana przez zajętych swoimi sprawami możniejszych tego świata ${ }^{56}$. Mógł więc i nasz przebieraniec, ubogi wiejski głupek, dostać się bez przeszkód na pole bitwy i tam rozeznać się dokładnie w sytuacji, nie wzbudzając niczyjego zainteresowania.

Szukając motywów posłużenia się przez Wincentego postacią przebranego kleryka, można także wziąć pod uwagę chęć podkreślenia braku związków biskupa z polem bitwy, oczywiście przy jednoczesnym dążeniu do wyjaśnienia czytelnikowi, skąd prałat czerpał swoje wiadomości o starciu mozgawskim. Rzecz istotna, bo uzyskane od owego „gońca" informacje stały się motorem dalszych działań hierarchy. Teraz, już bez żadnego kamuflażu, staje się on przywódcą i bierze sprawy w swoje ręce. Przy okazji wychodzą nie tylko jego talenty przywódcze, ale również

${ }^{53}$ M. Miller, Clothing the Clergy. Virtue and Power in Medieval Europe, Ithaca-London 2014, s. 20 n.

${ }^{54}$ Por. J. Banaszkiewicz, Atrybuty społeczne „ordines”. Kilka obrazków z X-XI wieku, w: idem, Trzy po trzy o dziesiątym wieku, Kraków 2014, szczeg. s. 228 n.

${ }_{55}$ Małgorzata Wilska (Błazen na dworze Jagiellonów, Warszawa 1998, s. 52) uważa, że termin ten może oznaczać błazna, szaleńca lub głupka. Najważniejszy dla tej badaczki był wszakże motyw przebrania, bo zmiana kostiumu odmieniała w średniowieczu człowieka tak dalece, że nie poznawali go przyjaciele i wrogowie.

56 J. Banaszkiewicz, Narrator w przebraniu, s. 429-431. Podany tu dla celów porównawczych przykład zaczerpnięty z jednego z dzieł Liutpranda z Cremony uzupełniłbym o przepyszne opowieści Balderyka z Florennes o Alberonie z Montreuil, późniejszym arcybiskupie Trewiru, który jeszcze będąc klerykiem w Metzu notorycznie miał korzystać z różnych przebrań, które pozwalały mu wychodzić z poważnych opresji w czasie wypełniania brawurowych misji politycznych czy też $\mathrm{w}$ trakcie ucieczek przed swoimi prześladowcami, Gesta Alberonis archiepiscopi auctore Balderico, wyd. G. Waitz, MGH SS, t. 8, Hannoverae 1848, s. 243-260. Zob. też G. Althoff, Christian Values and Noble Ideas of Rank and Their Consequences on Symbolic Acts, „e-Spania” 4, 2007, paragraf 13, <http:// e-spania.revues.org/4053> (dostęp 20 I 2016). 
fizyczne przygotowanie do znoszenia trudów wyprawy zbrojnej. Kronikarz nie napisał o tym wprost, ale trudno sobie wyobrazić, aby Pełka ścigał po nocy księcia Romana, jadąc wozem, nawet jeśli założymy, że ranny książę korzystał właśnie z takiego środka transportu. Tylko jazda wierzchem tłumaczy, dlaczego Rusini zostali w ogóle doścignięci, a rano biskup był znowu w pobliżu pola walki.

Rozmowa hierarchy z księciem ruskim, w czasie której zastanawiano się, co następnie należy uczynić, jest jasną przesłanką do tego, by uznać, że oto mamy do czynienia z naradą wojenną dowódców. Przy czym to książę Roman dowodził połączonymi siłami obrońców Krakowa na polu bitwy, co wyjaśniałoby, dlaczego ucieczka oddziałów ruskich wywołała wycofanie się ich śladem krakowian. Warto też przypomnieć sobie, że gdy pierwszy uciekinier z pola walki przybył do miejsca pobytu biskupa, to w rozmowie, która wywiązała się między nim a prałatem, imię Romana pojawia się dwukrotnie. To zastanawiające, że Pełka dowiaduje się, że „polegli pierwsi z naszych” i nie pyta o wojewodę Mikołaja, lecz interesuje go wyłącznie los księcia ruskiego. Zresztą wojewoda krakowski w ogóle nie został wspomniany z okazji starcia nad Mozgawą, a dowódcą walczącego tu rycerstwa krakowskiego uczynił go dopiero Jan Długosz ${ }^{57}$. Pogląd o dowodzeniu wojskami krakowsko-ruskimi na polu bitwy przez księcia ruskiego wzmacnia także przekaz Latopisu hipackiego, który przedstawił tę bitwę jako starcie między Mieszkiem III a Romanem ${ }^{58}$.

Roman dowodził zatem na polu bitwy, ale kierownictwo nad całą wyprawą sprawował niewątpliwie biskup Pełka. Sam fakt nie może dziwić. O ile osobiste uczestnictwo hierarchów kościelnych w walce nie było częste, o tyle dowodzenie oddziałami zbrojnymi nie było niczym nadzwyczajnym, choć czasem spotykało się z potępieniem. Analogii można by tu przedstawić tak wiele i z tak wielu rejonów Europy, nawet ograniczając się jedynie do wojen między chrześcijanami, że sięgnę tylko po jedną, ale bardzo bliską czasowo i terytorialnie. Otóż biskup praski Henryk Brzetysław, jednocześnie książę Rzeszy, w latach 1193-1194 zbrojnie usunął z Czech i Moraw księcia Przemysła Ottokara I, prowadząc w tych latach trzy duże wyprawy wojenne ${ }^{59}$.

Pogląd o przywódczej roli ordynariusza krakowskiego zyskuje dodatkowe wsparcie w opisie zdarzeń, które miały miejsce następnego dnia po bitwie. Po nocnej eskapadzie hierarcha wawelski jest ponownie w pobliżu

${ }^{57}$ Joannis Dlugosii Annales, lib. 6, s. 162.

58 Zbiór ogólny przywilejów i spominków mazowieckich, wyd. J.K. Kochanowski, t. 1, Warszawa 1919, nr 136.

${ }^{59}$ M. Smoliński, op. cit., s. 95 n. 
bitewnego pola, a wokół niego gromadzą się ocalałe hufce krakowskie, by odbyć z biskupem naradę wojenną. I znowu - tak jak wcześniej na wiecu odbytym po śmierci Kazimierza Sprawiedliwego - decydujący głos w kwestii dalszych działań przypada ordynariuszowi diecezji krakowskiej. Teraz jednak są to decyzje odnoszące się wprost do sztuki wojennej. To Pełka najpierw radzi („,presulis consilio”), by nie ścigać żadnego z Mieszków, a w końcu nakazuje wyruszyć do Krakowa ${ }^{60}$. Obraz taki nie zaskakuje i zapewne bliski był rzeczywistości. Nie od rzeczy będzie tu przypomnieć, że w połowie XII w. na Rusi, w otoczeniu utrzymującego bliskie stosunki z Polską księcia Izjasława II, krytycznie oceniano duchowieństwo łacińskie i wiedziano, że „biskupi ich nałożnice trzymają i na wojnę chodzą" ${ }^{1}$. Opinia ta odnosi się zapewne przede wszystkim do hierarchów z państw najlepiej na Rusi znanych, na czele z monarchią piastowską. Pogląd ten w odniesieniu zarówno do sfery militarnej, jak i seksualnej potwierdzają także ówczesne źródła polskie ${ }^{62}$.

Warto zwrócić uwagę na jeszcze jeden literacki zabieg kronikarza. Wobec poważnych wątpliwości związanych z udziałem biskupa krakowskiego w kampanii mozgawskiej, autor kroniki czynne zaangażowanie się Pełki w obronę Krakowa w roku 1191 oraz w obronę tronu krakowskiego dla potomstwa Kazimierza Sprawiedliwego kilka lat później stara się przykryć duszpasterską troską o powierzony mu lud Boży ${ }^{63}$. Pełka występuje wówczas jako kapłan (,antistes”, „presul”, „pontifex”), który działa na rzecz przezwyciężenia „zamętu i zamieszania w ludzkich stosunkach”, a działania te podejmuje jako „mąż pełen gorliwości Bożej”64.

60 „Iubet ergo ad sedem regni properari [--]”, Magistri Vincentii dicti Kadłubek Chronica Polonorum, s. 182.

${ }^{61}$ J.S. Gajek, Teodozjusz Grek i jego „Słowo o wierze chrześcijańskiej i łacińskiej”, w: Teologia i kultura duchowa starej Rusi, red. W. Hryniewicz, J.S. Gajek, Lublin 1993, s. 245. Zob. też F. Sielicki, Polsko-ruskie stosunki wyznaniowe w XI i XII wieku, w: Dzieło chrystianizacji Rusi Kijowskiej i jego konsekwencje w kulturze Europy, red. R. Łużny, Lublin 1988, s. 39.

${ }^{62}$ Poza Wincentym udział biskupów polskich w konfliktach zbrojnych potwierdza też kronika Anonima tzw. Galla: Galli Anonymi Cronicae et gesta, lib. III, c. 38, s. 108 oraz lib. III, c. 49, s. 119, zob. też M. Tomaszek, op. cit., s. 121-136; J. Dobosz, E. Skibiński, The Church in the Gallus Anonymous' Chronicle - Gallus within the Church, w: Gallus Anonymous and His Chronicle in the Context of Twelfth-Century Historiography from the Perspective of the Latest Research, red. K. Stopka, Kraków 2010, s. 78 n. oraz R. Kotecki, Lions and Lambs, zaś w kwestii celibatu: W. Wójcik, Prawo celibatu w Polsce średniowiecznej, „Roczniki Teologiczno-Kanonicze” 5, 1958, s. 63; A. Krawiec, Seksualność w średniowiecznej Polsce, Poznań 2000, s. 89-95; J. Maciejewski, Episkopat, s. 30, 165, 211 n.; K. Skwierczyński, Recepcja idei gregoriańskich w Polsce do początku XIII wieku, Wrocław 2005, s. 311-314.

${ }^{63}$ Por. D. Gerrard, Fighting Clergy, s. 276.

${ }^{64}$ Mistrz Wincenty (tzw. Kadłubek), Kronika polska, s. 244, 247. Natomiast nie ma powodu, aby uważać biskupa Pełkę za szczególnie pobożnego, co zasugerowała 
Także po bitwie mówi raczej jak duszpasterz niż wojownik, argumentując, że „nie godzi się prześladować tak udręczonego starca”, za to nakazuje zadbać o opuszczoną stolicę ${ }^{65}$. Na ten trop myślenia naprowadza nas sposób, w jaki dwunastowieczni kronikarze angielscy (John z Hexham oraz Richard z Hexham) przedstawili zaangażowanie się arcybiskupa Yorku Thurstana w obronę kraju przed najazdem szkockim w roku 1138, portretując go zarówno jako organizatora działań militarnych, jak i duchowego wojownika realizującego swoje funkcje duszpasterskie ${ }^{66}$. Krytyka w stosunku do takich postaw duchowieństwa w ówczesnym piśmiennictwie pojawia właściwie dopiero wówczas, gdy z punktu widzenia autora wypowiedzi bliskie związki jakiegoś prałata z rzemiosłem wojennym prowadziły do zakłócenia ładu społecznego.

Niekonsekwencja w przedstawieniu przez Wincentego postaci biskupa krakowskiego i podkreślanie, mimo oczywistego aktywnego zaangażowania kapłana w wyprawę zbrojną, jego roli duchowej, nie mogła być przypadkowa. Był to zapewne skutek obaw, jak opis działań Pełki, który inicjował i prowadził wojnę bez zgody papieskiej, a nawet wezwania swojego monarchy, w sposób zapewne sprzeczny z dobrze znanym Wincentemu stanowiskiem Gracjana ${ }^{67}$, może zostać przyjęty przez reformatorskiego i, co może ważniejsze, związanego z obozem książąt wielkopolskich metropolitę Henryka Kietlicza. Był on przecież także bliskim krewnym, może nawet synem, owego namiestnika, a później kasztelana krakowskiego Henryka Kietlicza, który w roku 1191 stanął na czele buntu przeciw

Brygida Kürbis, która przydany przez autora biskupowi przynależny jego pozycji epitet venerabilis przetłumaczyła w pewnym miejscu jako „świątobliwy”, por. Magistri Vincentii dicti Kadłubek Chronica Polonorum, s. 161; Mistrz Wincenty (tzw. Kadłubek), Kronika polska, s. 223.

${ }^{65}$ Mistrz Wincenty (tzw. Kadłubek), Kronika polska, s. 255. W podobny sposób, a nawet jeszcze dobitniej uzasadniał Wincenty polityczne zaangażowanie biskupa Gedki przeciwko rządom wielkopolskim w Krakowie: „Nec enim negligere aut silentio sepelire pius pastor quiquit tam erumpnosam sue cladem gregis absque sue salutis dispendio", Magistri Vincentii dicti Kadłubek Chronica Polonorum, s. 134.

${ }^{66}$ Continuation by John of Hexham, wyd. T. Arnold, w: Symeonis Monachi Opera, t. 2, London 1885, s. 292; Historia Ricardi, Prioris Ecclesiae Haugustaldensis, wyd. R. Howlett, w: Chronicles of the Reigns of Stephen, Henry II., and Richard I., t. 3, London 1886, s. 160; D. Gerrard, „The Military Activities of Bishops, Abbots, and other Clergy in England, c. 900-1200", niepublikowana rozprawa doktorska, University of Glasgow 2010, s. 174 n., http://theses.gla.ac.uk/2671/ (dostęp 28 I 2016); idem, Fighting Clergy, s. 276.

${ }^{67}$ O znajomości Dekretu Gracjana przez Wincentego zob. przede wszystkim A. Vetulani, Prawo kanoniczne i rzymskie w Kronice mistrza Wincentego, St. Źr. 20, 1976, s. 35-45, a ostatnio zwięzłe podsumowanie problemu i wykaz „przejątków” z dzieła Gracjana w Kronice polskiej dał: A. Lis, Spory wokół biografii mistrza Wincentego Kadłubka, Lublin 2013, s. $108 \mathrm{n}$. 
księciu Kazimierzowi Sprawiedliwemu ${ }^{68}$. Nie bez znaczenia musiała być także skomplikowana sytuacja Kościoła polskiego wobec konfliktu o tron krakowski, a także moralna ocena tego bratobójczego starcia. Nie wiemy przecież, jaką postawę wobec tego konfliktu zajęli ordynariusze ze śląska i Wielkopolski oraz metropolita gnieźnieński Piotr, ale można przypuszczać, że wspierali oni raczej „swoich” książąt.

Analizowana tu relacja mistrza Wincentego o udziale biskupa Pełki w wyprawie zbrojnej nad Mozgawę dobrze wpisuje się w wypracowany przez tego dziejopisa schemat portretowania biskupów na wojnie, zbliżając się przy tym do ujęcia dychotomicznego. Kronikarz popiera w tym przypadku postawę aktywną i nie widzi nic zdrożnego w uczestniczeniu biskupa w konflikcie zbrojnym. Stara się jednak pokazać jego zaangażowanie w taki sposób, by było jasne, że zachowywał się w sposób zgodny z wymogami oficjalnej wykładni prawa kanonicznego i poglądami autorytetów kościelnych, a nawet zdaje się sugerować, że była to realizacja jego posługi duszpasterskiej. Pochodzący z możnego rodu rycerskiego mistrz Wincenty świetnie rozumiał dążenie reprezentujących ordo clericalis przedstawicieli swojej grupy społecznej, którzy nie zatracili charakterystycznego dla wysokiego urodzenia instynktu bellatores. Tym bardziej że wobec wzmożonego nacisku na rezygnację z życia małżeńskiego hierarchom kościelnym pozostawało przywództwo polityczne i militarne, by potwierdzić swoją wartość w świecie wojowników, a jednocześnie pozostać w zgodzie ze swoim powołaniem ${ }^{69}$.

W odróżnieniu od wcześniejszych portretów wojowniczych biskupów płockich, relacja o Mozgawie jest jednak czymś więcej niż tylko literacką konstrukcją. Kronikarz musiał wszakże uwzględnić fakt, że opowiada o ludziach i wydarzeniach jemu współczesnych, a zatem wszystkim znanych. Stąd też tym razem czytelnik zostaje zapoznany z podstawowymi faktami o pobycie ordynariusza krakowskiego w okolicy, w której toczyły się zmagania zbrojne, oraz o podejmowaniu przez niego decyzji po zakończeniu bitwy. Mowa tu zatem o modlitwie błagalnej biskupa o rozsądzenie sporu przez Stwórcę, a także o zbawiennych radach, które z troską daje

${ }^{68}$ J. Bieniak [głos w dyskusji], w: Mistrz Wincenty Kadłubek - pierwszy uczony polskiw 750-lecie śmierci. Sympozjum naukowe zorganizowane w Poznaniu staraniem Poznańskiego Towarzystwa Przyjaciół Nauk i Polskiego Towarzystwa Historycznego w dniach 23 i 24 listopada 1973, St. Źr. 20, 1976, s. 124 n.; W. Baran-Kozłowski, Arcybiskup gnieźnieński Henryk Kietlicz (1199-1219). Działalność kościelna i polityczna, Poznań 2005, s. 52 n., 57-58 (rec. J. Maciejewski, KH 113, 2006, 2, s. 160 n.).

${ }^{69}$ Por. B. Arnold, op. cit., s. 163; K.A. Fenton, op. cit., s. 74 n. 
duszpasterz. Uważny czytelnik mógł jednak wyczytać i to, czego kronikarz nie napisał wprost, a mianowicie, iż Pełka był głównodowodzącym sił krakowsko-ruskich w tej kampanii zbrojnej, ale na polu walki dowództwo przypadło księciu Romanowi. Po bitwie jednak zorganizował wojsko i wydał rozkazy. Ponadto trudno mieć wątpliwości, że hierarcha wawelski wspierał swoje oddziały publiczną modlitwą w intencji zwycięstwa.

Powody strategii literackiej Wincentego zapewne nie miały swojego źródła w przepisach prawa kościelnego, zakazującego duchownym przelewania krwi, brak bowiem sugestii, że Pełka chwycił za broń lub dowodził bezpośrednio rozlewem krwi na polu bitwy. Ale już prowadzenie przez biskupa wojny bratobójczej mogło mieć istotne znaczenie. Można by oczywiście dopatrywać się także związku ze skomplikowaną sytuacją kościelno-polityczną, która charakteryzowała domenę piastowską na przełomie XII i XIII w., a zatem wówczas, gdy kronikarz tworzył ostatnie rozdziały swego dzieła. Zaważyć mógł przy tym fakt, że metropolitą był wówczas reformatorski arcybiskup Henryk Kietlicz, stronnik Mieszka III.

To jednak tylko jedna strona medalu. Nie mniej ważne było i to, że biskup Pełka nad Mozgawą, inaczej niż cztery lata wcześniej w Krakowie, okazał się, delikatnie rzecz ujmując - mało skuteczny - zarówno jako dowódca, jak i jako kapłan. Wszak wynik bitwy (porażka krakowian), mógł być interpretowany jako wyraz woli Bożej. W tej sytuacji trudno się dziwić, że główną myślą, która przyświecała kronikarzowi przy konstruowaniu przebiegu wypadków, była ochrona reputacji i autorytetu jego kościelnego zwierzchnika. A zatem: „po pierwsze nie szkodzić”.

\section{Streszczenie}

Artykuł dotyczy końca XII w., a zatem okresu, w którym tworzyła się Polska dzielnicowa. To wówczas, we wrześniu 1195 r., nad rzeczką Mozgawą doszło do jednej z największych bitew w XII-XIII w. Polsce, w której wojska krakowsko-ruskie, broniące praw sukcesyjnych synów Kazimierza Sprawiedliwego do tronu krakowskiego, zmierzyły się z idącymi na Kraków siłami wielkopolsko-śląskimi Mieszka III. W wojnie tej istotną rolę odegrał ordynariusz diecezji krakowskiej Pełka (1186-1207), a analiza relacji jego udziału w tym starciu spisanej przez mistrza Wincentego w Chronica Polonorum jest głównym tematem tej rozprawy.

Autor pokazał, że skonstruowany przez mistrza Wincentego portret biskupa Pełki oparty jest na wykorzystywanym przez tegoż kronikarza, a także przez wielu innych ówczesnych dziejopisów, dychotomicznym wzorcu biskupa, który łączył działalność duszpasterską z silnym zaangażowaniem w sprawy polityczne, w tym także militarne. W artykule przeanalizowano także powody, dla których kronikarz 
przedstawił działalność Pełki w sposób niekonsekwentny i dla czytelnika nieprzejrzysty. Narracja ta musiała bowiem uwzględnić wymagania stawiane duchowieństwu odnośnie do ich udziału w działaniach zbrojnych, a jednocześnie brała pod uwagę krytyczną opinię o wojnach domowych i niekorzystny dla strony krakowskiej wynik starcia mozgawskiego. Nie mniej istotna była zmienna sytuacja polityczna w Krakowie na przełomie XII i XIII w., a także reformistyczny nurt działalności arcybiskupa Henryka Kietlicza oraz jego powiązania polityczne i rodzinne. Autor sformułował także pewne wnioski odnoszące się do kwestii dowodzenia wojskami wiernymi Kazimierzowicom. Uznał mianowicie, iż w wyprawie mozgawskiej nie brał udziału, z nieznanych przyczyn, wojewoda Mikołaj, na polu bitwy połączonymi siłami krakowsko-ruskimi dowodził książę Roman, a wodzem całej sojuszniczej armii był wówczas biskup krakowski Pełka.

\section{Bishop of Cracow Pełka and the Battle of Mozgawa in 1195}

The article focuses on the end of the twelfth century, the early stage of feudal fragmentation in Poland. At that time, in September 1195, on the small river of Mozgawa one of the greatest Polish battles of the twelfth and thirteenth centuries was fought, in which the Cracow and Ruthenian troops in defence of the succession rights of Duke Casimir II the Just's sons to the Cracow throne, pitted themselves against Duke Mieszko III the Old's forces of Greater Poland and Silesia marching towards Cracow. An important role in the war was played by the ordinary of the Cracow diocese Pełka (1186-1207), and an analysis of the account of his participation in the fight, written by Master Vincentius in his Chronica Polonorum is the main topic of the present study.

The author has demonstrated that his portrait of Bishop Pełka Master Vincentius based on a dichotomous model of bishop - used also by many other chroniclers of his times - who combined the pastoral care with strong personal engagement in political matters, including military ones. There is also an analysis of the reasons that made the chronicler to present Bishop Pełka's actions in an inconsistent and unclear manner for the reader. But the narrative had to both comply with the requirements imposed on the clergy in relation to their participation in military actions, and to take into consideration critical opinions on civil wars and the unfavourable result of the battle for the Cracow party.

No less important were changing political circumstances in Cracow at the turn of the thirteenth century, but also a reformatory activity of Archbishop Henryk Kietlicz, together with his political and family ties. The author reached several conclusions as to the question of command of the troops faithful to the Casimir's sons. He found in particular that, for unknown reasons, the governor of the province Mikołaj did not participate in the Mozgawa Battle, and the Cracow and Ruthenian joint forces were fighting under the command of Duke Roman, while the whole army was commanded by Bishop of Cracow Pełka. 


\section{Bibliografia}

\section{Źródła}

Anonim tzw. Gall, Kronika polska, tłum. Roman Grodecki, Ossolineum, Wrocław 1989. Continuation by John of Hexham, wyd. Arnold Thomas, w: Symeonis Monachi Opera omnia, t. 2, London 1885, ss. 284-332 (repr. Cambridge University Press, Cambridge 2014).

Chronica Adefonsi imperatoris, wyd. Luis Sánchez Belda, CSIC, Madrid 1950.

Długosz Jan, Liber beneficiorum dioecesis Cracoviensis, t. 3, w: Joannis Dlugossi Opera omnia, wyd. Aleksander Przeździecki, t. 9, Kraków 1864.

Galli Anonymi Cronicae et gesta ducum sive principium Polonorum, wyd. Karol Maleczyński, MPH s.n., t. 2, PAU, Kraków 1952.

Gesta Alberonis archiepiscopi auctore Balderico, MGH Scriptores, wyd. Georg Waitz, t. 8, Hannoverae 1848 .

Heinrici Chronicon Livoniae, wyd. 2, wyd. Leonid Arbusow, Albert Bauer, MGH SrG, Hannoverae 1955.

Historia Ricardi, Prioris Ecclesiae Haugustaldensis, wyd. Richard Howlett, w: Chronicles of the Reigns of Stephen, Henry II., and Richard I., t. 3, Longman and Trübner, London 1886.

Izydor z Sewilli, Etymologiarum libri XX, PL, t. 82, Paris 1850.

Joannis Dlugosii Annales seu cronicae Incliti Regni Poloniae, lib. 5-6, t. 3, wyd. Zofia Kozłowska-Budkowa et al., PWN, Warszawa 1973.

Kodeks dyplomatyczny katedry krakowskiej ś. Wacława, wyd. Franciszek Piekosiński, cz. 1, Akademia Umiejętności, Kraków 1874.

Magistri Vincentii dicti Kadłubek Chronica Polonorum, wyd. Marian Plezia, MPH s.n., t. 11, PAU, Kraków 1994.

Maistre Wace's Roman de Rou et des Ducs de Normandie, wyd. Hugo Andresen, Verlag von Gebr. Henninger, Heilbronn 1879.

Mistrz Wincenty (tzw. Kadłubek), Kronika polska, tłum. Brygida Kürbis, Ossolineum, Wrocław 1992.

Rocznik świętokrzyski, wyd. Anna Rutkowska-Płachcińska, MPH s.n., t. 12, PAU, Kraków 1996.

Vita Balderici episcopi Leodiensis, MGH Scriptores, 4, wyd. Georg H. Pertz, Hannoverae 1841.

Zbiór ogólny przywilejów i spominków mazowieckich, wyd. Jan K. Kochanowski, t. 1, Warszawa 1919.

\section{Opracowania}

Althoff Gerd, Christian Values and Noble Ideas of Rank and Their Consequences on Symbolic Acts, „e-Spania” 4, 2007, paragraf 13, <http://e-spania.revues.org/4053>.

Arranz Guzmán Ana, Cuando el clérigo va a la Guerra. Algunos ejemplos de obispos „peleadores", w: Guerra y paz en la Edad Media, red. eadem, María del Pilar Rábade Obradó, Óscar Villarroel Gonzáles, Silex, Madrid 2013, s. 275-308. 
Arnold Benjamin, Medieval German Bishops and their Military Retinues in the Medieval Empire, „German History” 7, 1989, 2, s. 161-183.

Bachrach David, Religion and the Conduct of War, c.300-c.1215, The Boydell Press, Woodbridge 2003.

Bachrach David, Military Chaplains and the Religion of War in Ottonian Germany, 9191024, „Religion, State and Society” 39, 2011, 1, s. 13-31.

Banaszkiewicz Jacek, Narrator w przebraniu, czyli Mistrz Wincenty o bitwie mozgawskiej, w: „Onus Athlanteum”. Studia nad Kroniką biskupa Wincentego, red. Andrzej Dąbrówka, Witold Wojtowicz, Pro Cultura Literaria i IBL PAN Warszawa 2009, s. 423-434.

Banaszkiewicz Jacek, Atrybuty społeczne „ordines”. Kilka obrazków z X-XI wieku, w: idem, Trzy po trzy o dziesiatym wieku, Avalon, Kraków 2014, s. 221-240.

Baran-Kozłowski Wojciech, Arcybiskup gnieźnieński Henryk Kietlicz (1199-1219). Działalność kościelna i polityczna, Wydawnictwo Poznańskie, Poznań 2005.

Bartos Sebastian, „Negotiations of Power in a Medieval Society. Ecclesiastical Authority and Secular Rulership in Little Poland, 1177-1320", praca doktorska obroniona na University of New York, 2008.

Bartos Sebastian, Post-Gregorian Episcopal Authority and the Struggle for Ducal Krakow, 1177-1210, „The Polish Review” 58, 2013, 3, s. 3-33.

Bieniak Janusz, Bieniak [głos w dyskusji], w: Mistrz Wincenty Kadłubek - pierwszy uczony polski - w 750-lecie śmierci. Sympozjum naukowe zorganizowane w Poznaniu staraniem Poznańskiego Towarzystwa Przyjaciół Nauk i Polskiego Towarzystwa Historycznego w dniach 23 i 24 listopada 1973, St. Źr. 20, 1976, s. 123-124.

Bieniak Janusz, Polska elita polityczna XII wieku (cz. 1: Tło działalności), w: Społeczeństwo Polski średniowiecznej, t. 2, red. Stefan K. Kuczyński, DiG, Warszawa 1982, s. 11-61.

Bieniak Janusz, Polska elita polityczna XII wieku (cz. IIID: Arbitrzy książą - zmierzch), w: Społeczeństwo Polski średniowiecznej, t. 9, red. Stefan K. Kuczyński, DiG, Warszawa 2001, s. 9-53.

Chmielewska Katarzyna, Recepcja rzymskiej literatury antycznej $w$ „Kronice polskiej” Mistrza Wincentego, w: „Onus Athlanteum”. Studia nad Kronika biskupa Wincentego, red. Andrzej Dąbrówka, Witold Wojtowicz, IBL PAN, Pro Cultura Literaria, Warszawa 2009, s. 215-230.

Clauss Martin, Der Krieg als Mittel und Thema der Kommunikation. Die Narrative Funktion des Gottesurteils, w: Gottes Werk und Adams Beitrag. Formen der Interaktion zwischen Mensch und Gott im Mittelalter, red. Thomas Honegger, Gerlinde Huber-Rebenich, Volker Leppin, De Gruyter, Berlin 2014, s. 128-141.

Dobosz Józef, Monarchia i możni wobec Kościoła w Polsce do początku XIII wieku, Wydawnictwo Poznańskie, Poznań 2002.

Dobosz Józef, Skibiński Edward, The Church in the Gallus Anonymous' Chronicle - Gallus within the Church, w: Gallus Anonymous and His Chronicle in the Context of Twelfth-Century Historiography from the Perspective of the Latest Research, red. Krzysztof Stopka, PAU, Kraków 2010, s. 75-89.

Duggan Lawrence, Armsbearing and the Clergy in the History and Canon Law of Western Christianity, The Boydell Press, Woodbridge 2013.

Fenton Kirsten A., Writing Masculinity and Religious Identity in Henry of Huntingdon, w: Religious Men and Masculine Identity in the Middle Ages, red. P.H. Cullum, Katherine J. Lewis, The Boydell Press, Woodbridge 2013, s. 64-76. 
Gajek Jan S., Teodozjusz Grek i jego „Słowo o wierze chrześcijańskiej i łacińskiej”, w: Teologia i kultura duchowa starej Rusi, red. Wacław Hryniewicz, Jan S. Gajek, Wydawnictwo KUL, Lublin 1993.

Gerrard Daniel, Fighting Clergy, Church Councils and the Contexts of Law. The Cutting Edge of Orthodoxy or the Ambiguous Limits of Legitimacy, w: Heresy and the Making of European Culture. Medieval and Modern Perspectives, red. Andrew P. Roach, James R. Simpson, Ashgate, Farnham-Burlington 2013, s. 275-288.

Gerrard Daniel, „The Military Activities of Bishops, Abbots, and other Clergy in England, c. 900-1200", niepublikowana rozprawa doktorska, University of Glasgow 2010, http://theses.gla.ac.uk/2671/.

Jasiński Kazimierz, Rodowód Piastów ślaskich, t. 1: Piastowie wrocławscy i legnicko-brzescy, Wrocławskie Towarzystwo Naukowe, Wrocław 1973.

Jensen Carsten S., Bishops and Abbots at War. Some Aspects of Clerical Involvement in Warfare in Twelfth and Early Thirteenth Century Livonia and Estonia, w: Between Sword and Prayer. Warfare and Medieval Clerical World in Cultural Perspective, red. Radosław Kotecki, Jacek Maciejewski, John S. Ott, Brill, Leiden-Boston 2018, s. 404-434.

Kiechhefer Richard, Magic in the Middle Ages, Cambridge University Press, Cambridge 2014.

Keupp Johann, Die Zwei Schwerter des Bischofs. Von Kriegsherren und Seelenhirten im Reichsepiskopat der Stauferzeit, „Zeitschrift für Kirchengeschichte” 117, 2006, s. $1-24$.

Kotecki Radosław, Ordynariusz płocki Szymon w Gallowej narracji o bitwie Mazowszan $z$ Pomorzanami, w: Ecclesia et bellum. Kościół wobec wojny i zaangażowania militarnego duchowieństwa w wiekach średnich, red. Radosław Kotecki, Jacek Maciejewski, Bydgoszcz 2016, s. 142-167.

Kotecki Radosław, Lions and Lambs, Wolves and Pastors of the Flock. Portraying Military Activities of Bishops in Twelfth Century Poland. A Comparative View, w: Between Sword and Prayer. Warfare and Medieval Clerical World in Cultural Perspective, red. Radosław Kotecki, Jacek Maciejewski, John S. Ott, Brill, Leiden-Boston 2018, s. 303-340.

Kotecki Radosław, With the Sword of Prayer, or How the Medieval Bishop Should Fight, "Questiones Medii Aevii Novae” 21, 2016, s. 343-371.

Krawiec Adam, Seksualność w średniowiecznej Polsce, Wydawnictwo Poznańskie, Poznań 2000.

Kürbis Brygida, Jak mistrz Wincenty pisał historię Polski, w: Mistrz Wincenty Kadłubek. Człowiek i dzieło, pośmiertny kult i legenda, red. Krzysztof Prokop, PAU, Kraków 2001, s. 59-78.

Lapina Elisabeth, Warfare and the Miraculous in the Chronicles of the First Crusade, The Pennsylvania State University Press, Philadelphia 2015.

Lis Artur, Spory wokół biografii mistrza Wincentego Kadłubka, Wydawnictwo KUL, Lublin 2013.

Litak Stanisław, Struktura terytorialna Kościoła łacińskiego w Polsce w roku 1772, Wydawnictwo KUL, Lublin 1979.

Lund Niels, The Military Obligations of the Danish Church in the High Middle Ages, w: The Medieval Way of War. Studies in Medieval Military History in Honor of Bernard S. Bachrach, red. Gregory I. Halfond, Ashgate, Farnham-Burlington 2015, s. 295-307. 
Łowmiański Henryk, Początki Polski, t. 6/1, PWN, Warszawa 1985.

Maciejewski Jacek, A Bishop Defends His City, or Master Vincentius's Troubles with the Military Activity of His Superior, w: Between Sword and Prayer. Warfare and Medieval Clerical World in Cultural Perspective, red. Radosław Kotecki, Jacek Maciejewski, John S. Ott, Brill, Leiden-Boston 2018, s. 341-368.

Maciejewski Jacek, Episkopat polski doby dzielnicowej 1180-1320, Societas Vistulana, Kraków-Bydgoszcz 2003.

Maciejewski Jacek, Precedencja biskupów polskich w Polsce piastowskiej, „Nasza Przeszłość" 99, 2003, s. 5-26.

Maleczyński Karol, Jarosław, książę opolski, biskup wrocławski, PSB, t. 11, Wrocław 1964-1965, s. 1.

Mika Norbert, Mieszko. Książę raciborski i pan Krakowa. Dzielnicowy władca Polski (ok. 1142-1211), Avalon, Kraków 2010.

Miller Maureen, Clothing the Clergy. Virtue and Power in Medieval Europe, Cornell University Press, Ithaca-London 2014.

Nelson Janet L., The Church's Military Service in the Ninth Century. A Contemporary View?, w: Politics and Ritual in Early Medieval Europe, red. eadem, The Hamblendon Press, London 1986, s. 117-132.

Pauk Marcin R., Wółkiewicz Ewa, „Ministri enim altaris ministri curiae facti sunt”. Ottońsko-salicki „system” Kościoła Rzeszy i jego oddziaływanie w Europie Środkowo-Wschodniej w XI-XII wieku, w: Kościół w monarchiach Przemyślidów i Piastów, red. Józef Dobosz, Wydawnictwo Poznańskie, Poznań 2009, s. 105-138.

Prinz Franz E., Klerus und Krieg im früheren Mittelalter. Untersuchungen zur Rolle der Kirche beim Aufbau der Königsherrschaft, Hiersemann, Stuttgart 1971.

Przybył Maciej, Mieszko III Stary, Wydawnictwo Poznańskie, Poznań 2002.

Rajman Jerzy, Mieszko Plątonogi, pierwszy książę raciborsko-opolski (1173-1211), KH 19, 1996, 1, s. 23-41.

Reid Jr. Charles J., The Rights of Self-Defence and Justified Warfare in the Writings of the Twelfth and Thirteenth-Century Canonists, w: Law as Profession and Practice in Medieval Europe. Essays in Honor of James A. Brundage, red. Kenneth Pennington, Ashgate, Farnham-Burlington 2011, s. 73-91.

Reuter Tymothy, „Episcopi cum sua militia”. The Prelate as Warrior in the Early Staufer Era, w: Warriors and Churchmen in the High Middle Ages, red. idem, The Hambledon Press, London-Rio Grande 1992.

Reynolds Roger E., Clerical Orders in the Early Middle Ages. Duties and Ordination, Ashgate, Aldershot-Brookfield-Singapore-Sydney 1999.

Russell Frederick H., The Just War in the Middle Ages, Cambridge University Press, Cambridge 1975.

Sielicki Franciszek, Polsko-ruskie stosunki wyznaniowe w XI i XII wieku, w: Dzieło chrystianizacji Rusi Kijowskiej i jego konsekwencje w kulturze Europy, red. Ryszard Łużny, Wydawnictwo KUL, Lublin 1988, s. 35-49.

Skwierczyński Krzysztof, Recepcja idei gregoriańskich w Polsce do początku XIII wieku, Wydawnictwo UWr, Wrocław 2005.

Smirnova Victoria, No Way to Salvation for German Bishops? The Case of St. Engelbert of Cologne, w: Saintly Bishops and Bishops' Saints, red. John S. Ott, Trpimir Verdiš, Humaniora, Zagreb 2012, s. 183-200. 
Smoliński Marek, Sojusze Mieszka III Starego przed bitwą mozgawska, „Przegląd Zachodniopomorski" 21, 2006, 4, s. 83-105.

Smolka Stanisław, Mieszko Stary i jego wiek, Gebethner i Spółka, Warszawa 1881.

Szczur Stanisław, Biskupi krakowscy w Polsce piastowskiej. Między tronem a ołtarzem, w: Katedra krakowska w średniowieczu. Materiały sesji oddziału krakowskiego Stowarzyszenia Historyków Sztuki, red. Joanna Daranowska-Łukaszewska, Kazimierz Kuczman, Oddział Krakowski SHS, Kraków 1996, s. 9-24.

Tomaszek Michał, Modlitwa i łzy bronia biskupa. Pasterze polskiego Kościoła a walka orężna w ujęciu Wincentego Kadłubka, RH 71, 2005, s. 121-136.

Vetulani Adam, Prawo kanoniczne i rzymskie w Kronice mistrza Wincentego, St. Źr. 20, 1976, s. 35-45.

Wilska Małgorzata, Błazen na dworze Jagiellonów, Neriton, IH PAN, Warszawa1998.

Wasilewski Tadeusz, O służbie wojskowej ludności wiejskiej i składzie społecznym wojsk konnych i pieszych we wczesnym średniowieczu polskim, PH 51, 1960, 1, s. 1-23.

Webb Jeffrey Robert, Representations of the Warrior-Bishop in Eleventh-Century Lotharingia, „Early Medieval Europe” 24, 2016, 1, s. 103-130.

Wiszewski Przemysław, Polska $w$ kronice Mistrza Wincentego. Ze studiów nad terminologia dzieła i hierarchiami wartości w Polsce pełnego średniowiecza, w: „Onus Athlanteum”. Studia nad Kroniką biskupa Wincentego, red. Andrzej Dąbrówka, Witold Wojtowicz, IBL PAN, Pro Cultura Literaria, Warszawa 2009, s. 75-90.

Włodarski Bronisław, Polska i Ruś 1194-1340, PWN, Warszawa 1966.

Wolverton Lisa, Cosmas of Prague. Narratives, Classicism, Politics, The Catholic University of America Press, Washington 2015.

Wójcik Walenty, Prawo celibatu w Polsce średniowiecznej, „Roczniki Teologiczno-Kanonicze" 5, 1958, s. 55-82.

Biogram: prof. dr hab. Jacek Maciejewski, profesor zwyczajny, Uniwersytet Kazimierza Wielkiego w Bydgoszczy; główne zainteresowania naukowe: Kościół a wojna i przemoc w średniowieczu, modele kariery wyższego duchowieństwa, uczestnictwo kleru w społecznym, kulturalnym oraz politycznym życiu Polski średniowiecznej; kontakt: jmac@ukw.edu.pl. 